\title{
SCAPHOSEPALUM ZIEGLERAE, A SHOWY NEW SPECIES IN THE GENUS (PLEUROTHALLIDINAE: ORCHIDACEAE)
}

\author{
Luis E. BAquero R. ${ }^{1,2,3}$
}

${ }^{1}$ Carrera de Ingeniería Agroindustrial y Alimentos. Facultad de Ingeniería y Ciencias Agropecuarias. Universidad de Las Américas, Calle José Queri, Quito 170137, Pichincha, Ecuador

${ }^{2}$ Jardín Botánico de Quito, Quito, 170135, Pichincha, Ecuador

${ }^{3}$ Instituto Nacional de Biodiversidad, Quito, Pichincha, Ecuador

lbaquero@hotmail.com

ABstRact. Scaphosepalum zieglerae is described from a small area near Chical in northern Ecuador. It is distinguished by the large plant, waxy yellow flowers densely spotted with brown red to blood-red, spiky tails of the lateral sepals and a dark blood-red, wingless lip. It is here compared to Scaphosepalum beluosum with which it shares most similarities, and to $S$. fimbriatum, another species with fimbriated sepaline tails.

KEY words: Ecuador, new species, osmophores, Scaphosepalum beluosum, S. fimbriatum, S. zieglerae

Introduction. Scaphosepalum Pfitz. is a genus in the subtribe Pleurothallidinae with up to 52 species generally accepted (Pridgeon 2005, Endara et al. 2011, Chase et al. 2015, Karremans 2016, Karremans et al. 2016). After Luer (1988), who recognized three sections and 30 species in his monograph, several new species have been described in the last twenty-five years (Luer 1991, 1992, 1997, 1998a, b, 2000, 2002, 2009, Valenzuela Gamarra 2015). The characteristic features of the genus are the osmophores at the base of the sepals and the non-resupinate flowers (Luer 1988, Pridgeon et al. 2005, Endara et al. 2011, Karremans et al. 2016). The peak of diversity of the genus is in the northern Andes, between Colombia and Ecuador. Preliminary phylogenetic studies show strong biogeographic components affecting the distribution and isolation of different taxa within Scaphosepalum (Endara, Williams \& Whitten 2011). Some species seem to have wide ranges like Scaphosepalum breve (Rchb.f.) Rolfe or Scaphosepalum swertiifolium (Rchb.f.) Rolfe while others seem to be endemic to certain areas like Scaphosepalum dodsonii Luer, S. hirtzii Luer, or S. ursinum Luer (Luer 1988, Endara et al. 2011). The most recent phylogenetic study that includes Scaphosepalum suggests that the genus is related to Teagueia and close to Platystele (Karremans et al. 2016).

The north-west of Carchi province is one of the areas with high species diversity in Ecuador, where at least six species occur: Scaphosepalum decorum Luer \& Escobar, S. cimex Luer \& Hirtz, S. ophidion Luer, $S$. reptans Luer \& Hirtz, S. swertiifolium and S. ursinum Luer (Luer 1988, 2009). A conspicuous new species of Scaphosepalum, found in the same area, close to Maldonado in Carchi, is described here.

Scaphosepalum zieglerae Baquero, sp. nov. (Fig. 1, 2B, 3A-D).

TYPE: Ecuador, Carchi, El Carmen - Chical road, $0^{\circ} 54^{\prime} 42.5^{\prime} \mathrm{N} 78^{\circ} 12^{\prime} 48.7^{\prime \prime} \mathrm{W}, 1755 \mathrm{~m}$, collected by Luis Baquero on 15 March 2016, LB 3026 (holotype, QCNE).

Diagnosis: Species with large plants and long, thin petiolate leaves, vegetatively similar to Scaphosepalum beluosum Luer from which it differs by the dark green, subplicate leaves instead of conduplicate, light green to green, a caudate apex of the leaf instead of subacute, the flexuous inflorescence with conspicuous acuminate bracts instead of non-flexuous with thin, tubular floral bracts, the ovary smooth instead of speculate, the tails of the sysnsepal fimbriate instead of ciliate-spiculate, and the dark blood-red, subpandurate lip instead of green dotted with purple, subpandurate-ligulate, with lateral lobes above the middle. 


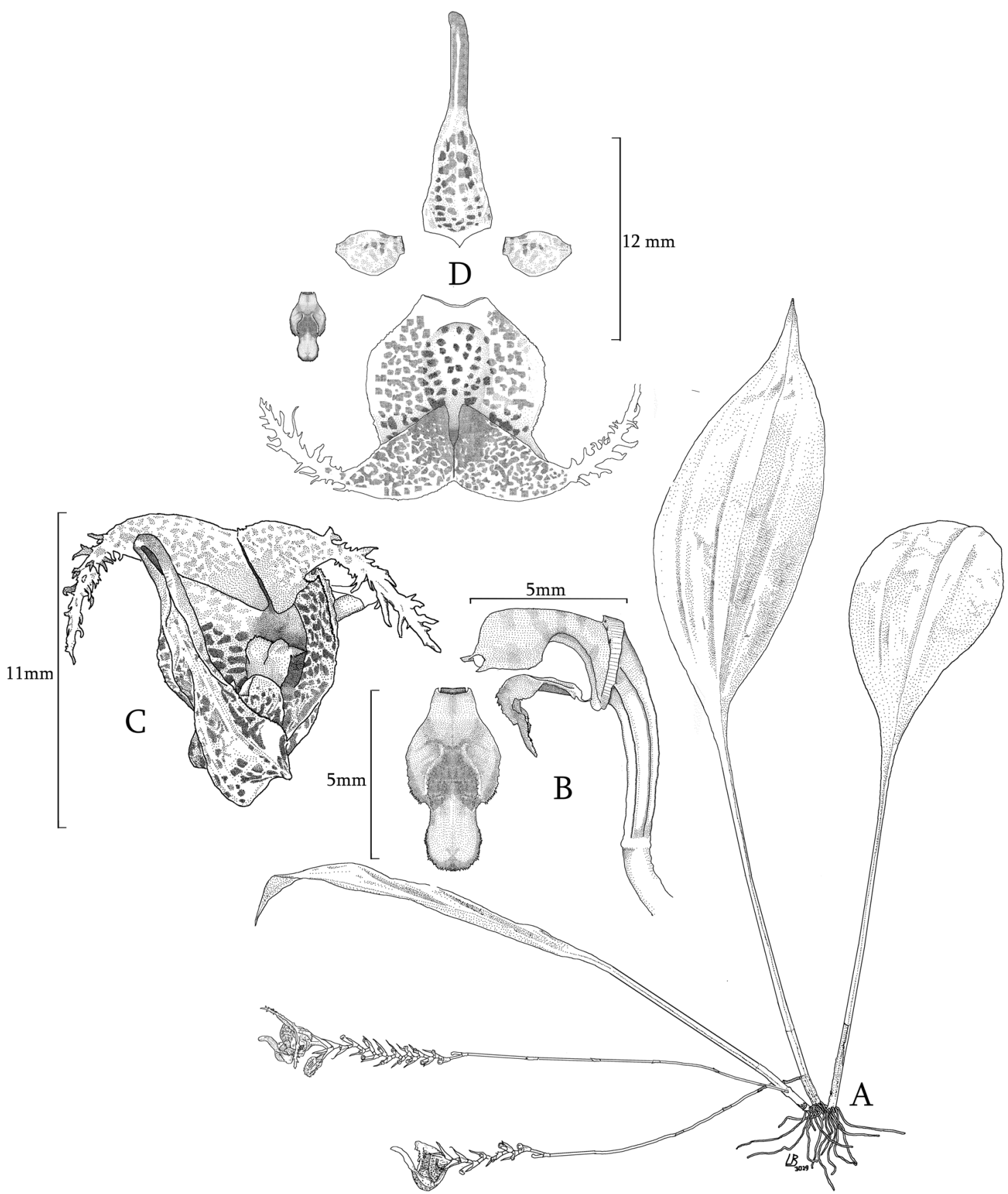

FIgURE 1. Scaphosepalum zieglerae Baquero. A, gabit. B, column and lip (the lip extended). C, flower. D, dissected flower.

Drawn by L. Baquero from the holotype.

Plant large, robust, epiphytic, densely caespitose, to $30 \mathrm{~cm}$ tall. Roots slender, $0.8 \mathrm{~mm}$ in diameter. Ramicauls erect, slender, $2-4 \mathrm{~cm}$ long, enclosed by $2-3$ sheets. Leaf erect, thinly coriaceous, subplicate, longLANKESTERIANA 17(2). 2017. (C) Universidad de Costa Rica, 2017. petiolate, $20-35 \mathrm{~cm}$ long including the petiole $8-15 \mathrm{~cm}$ long, leaf apex caudate $2-3 \mathrm{~cm}$ long, the blade elliptical 4.0-6.5 cm wide, attenuate below into the slender, channeled petiole. Inflorescence a loose, flexuous, 

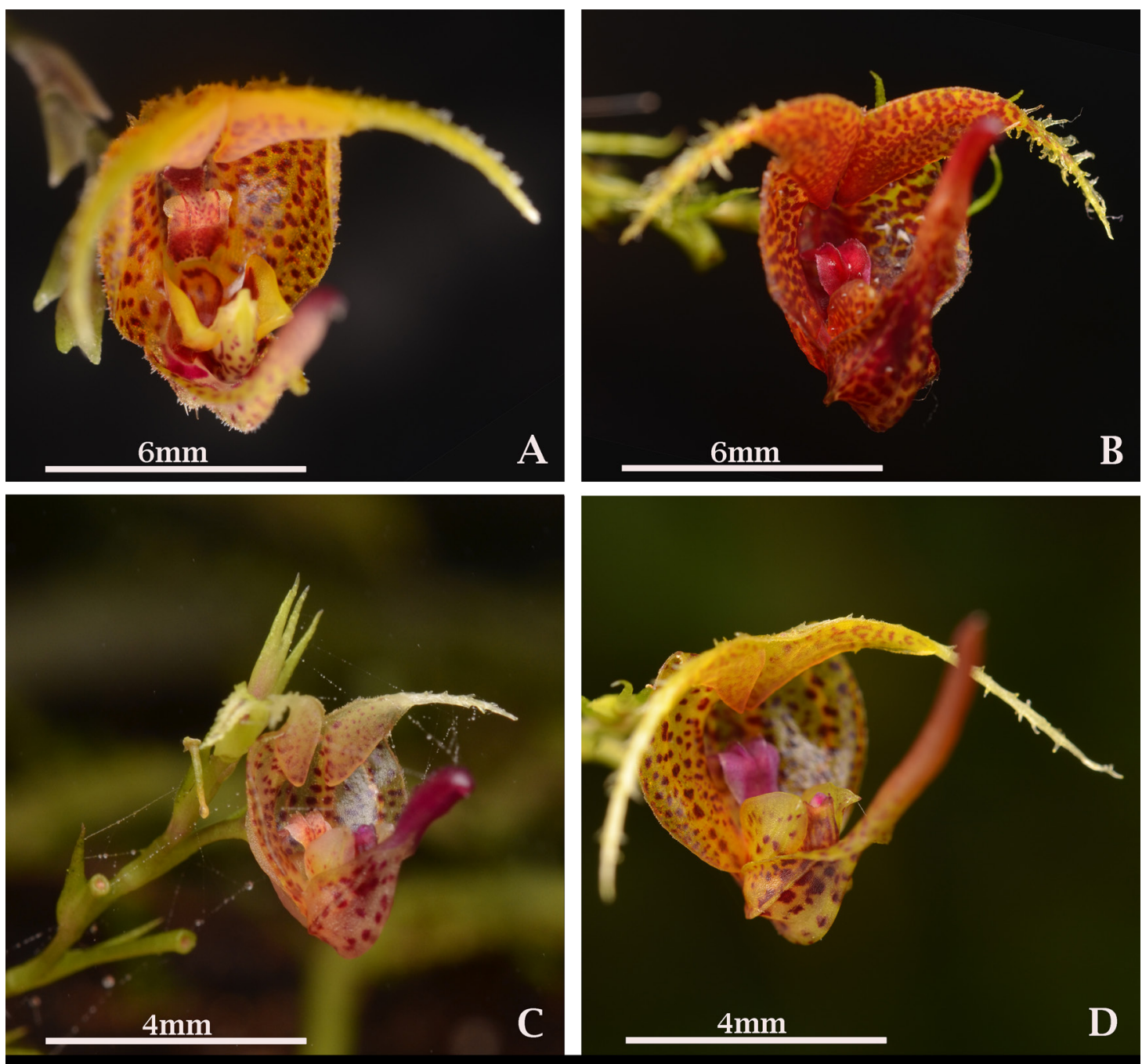

FiguRE 2. Different species of Scaphosepalum. A, S. beluosum. B, S. ziegleriae C, S. ophidion. D, S. reptans.

successively several to many-flowered raceme from low on the ramicaul, 12-20 cm long, each flower borne by a slender, faintly verrucose, horizontal peduncule 11-18 cm long; floral bracts thin, conspicuous, longer than the pedicel, conduplicate, acuminate, $9 \mathrm{~mm}$ long; pedicel 3-5 mm long, ovary ribbed, $5 \mathrm{~mm}$ long. Sepals waxy yellow, spotted with reddish brown to blood-red, ciliated margins, with dentate carinae, the middle sepal tricarinate, ovate and concave in the lower half, $14 \times$ $4 \mathrm{~mm}$ in natural position, the apical half brownish red, narrowly tubular with revolute margins, the lateral sepals connate $10 \mathrm{~mm}$ into a bifid, oblong, concave lamina 6 mm unexpanded, the apical portion of each lateral sepal occupied by a thick, triangular, diverging, glabrous cushion $3.5 \times 4 \mathrm{~mm}$, continuous with the acute, oblique, diverging apex terminating in a decurved, fimbriate tail, the total length of each lateral sepal including the tail 16 $\mathrm{mm}$ long. Petals waxy yellow, spotted with red-brown, longitudinal callous medially, obliquely ovate, acute, slightly reflexed at apex, $4 \times 3 \mathrm{~mm}$, the labellar margin obtusely angled, the upper margin slightly dilated. Lip dark blood-red, oblong-subpandurate, reflexed near the middle, $5.0 \times 2.5 \mathrm{~mm}$, the epichile obtuse, ciliate to fringed at the edge, the disc with a pair of tall, erect, serrated lamellae above the middle, the hypochile rectangular, slightly concave, the base truncate, minutely bilobulate. Column red, semiterete, slender, $4.5 \mathrm{~mm}$, broadly winged above the middle, with a thick 

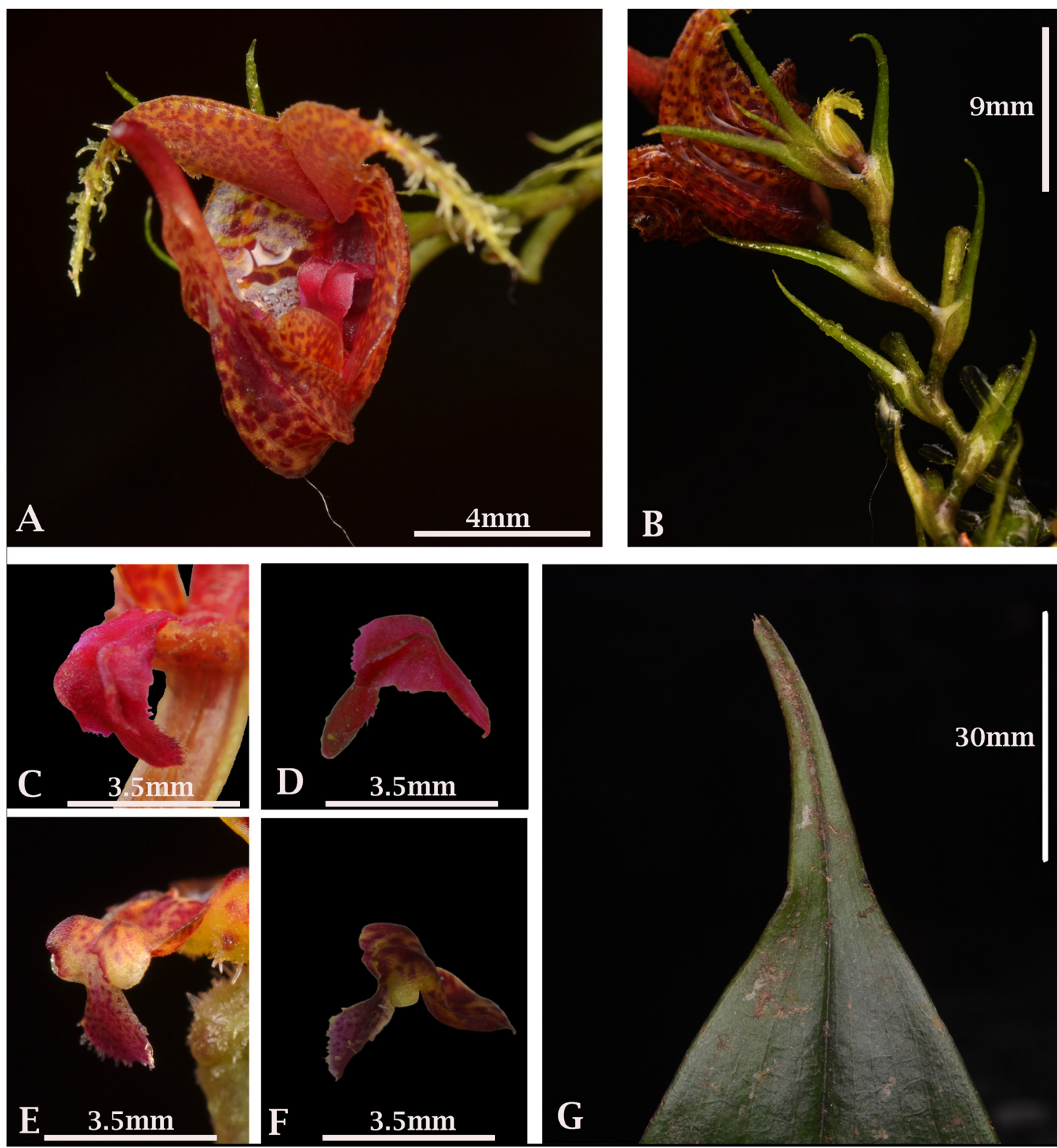

FIgURE 3. Scaphosepalum zieglerae flower and parts. A, flower. B, inflorescence and floral bracts. C, lip of Scaphosepalum zieglerae in $3 / 4$ position. D, lip of Scaphosepalum zieglerae, lateral view. E, lip of Scaphosepalum beluosum Luer in $3 / 4$ position. F, lip of Scaphosepalum beluosum Luer, lateral view. G, caudate apex and dark green color of the leaf of Scaphosepalum zieglerae.

foot $2.5 \mathrm{~mm}$ long. Pollinia 2, yellow. Fruits and seeds not observed.

Eponymy: Named after Susann Ziegler Annen, of Switzerland, important donor and promoter of Ecominga Foundation's Dracula Reserve, Ecuador, who made it possible to purchase and protect large LANKESTERIANA 17(2). 2017. (C) Universidad de Costa Rica, 2017. areas of primary forest hosting this new species and many other species.

Distribution: One population of Scaphotsepalum zieglerae has been found growing in primary cloud forest in north-western Ecuador. Plants found in two mountain ridges, close to each other, where they 
are fairly common between $1790 \mathrm{~m}$ and $1850 \mathrm{~m}$ of elevation, around $\mathrm{km} 7$ of the Chical-El Carmen road in the province of Carchi, Ecuador.

Habitat AND Ecology: Scaphosepalum zieglerae is found growing on the base of trunks of big trees in primary cloud forest at $\sim 1800 \mathrm{~m}$ of elevation. Large plants can be seen growing in very dark areas, where heavily filtered sunlight reaches the low understory of the forest. The dark, large leaves of $S$. zieglerae only compete in size with the big long-stem leaves of $S$. decorum. Other species of Scaphosepalum like S. cimex, $S$. decorum, $S$. ophidion, $S$. reptans and $S$. swertiifolum were found living in sympatry with this species.

Conservation Status: The population of Scaphosepalum zieglerae is under protection of the Ecominga Foundation at the Dracula Reserve, close to the Cerro Colorado sector. Extensive exploration has been done around the area by the team of orchid specialists from Ecominga for almost a decade and no other populations have been found. The Blanco river and the almost vertical walls of the Pailon ridge could act as natural barriers perhaps limiting its distribution; it is possibly more restricted than other Scaphosepalum species ( $S$. swertiifolium, $S$. decorum and S. ophidion) growing sympatrically, which are found in many other localities in Carchi and around Ecuador, and also in Colombia (Luer 1988, 2009). Perhaps more research in the field and in neighboring Colombia will lead to the discovery of new populations of S. zieglerae.

Scaphosepalum zieglerae is recognized among the species of Scaphosepalum by a unique combination of characters: the large, long petiolate, dark-green leaves, the caudate leaf apex and, specially, the flowers with spiky tails and dark blood-red colored lip (Fig. 1, 2 and 3). Scaphosepalum zieglerae looks superficially similar to S. beluosum, mainly because of the long petiolate plants and lateral inflorescences. In addition, it seems that $S$. zieglerae and $S$. ophidion could be related because they share long flexuous racemes with conspicuous acuminate bracts, fimbriate tails of the synsepal and the oblong-subpandurate lip (Fig. 1, 2). Scaphosepalum zieglerae shares with S. fimbriatum Luer \& Hirtz the fimbriated sepaline tails, but it differs from the latter species by the size of the plants, the shape and length of the leaves, and the size and general morphology of the flowers.
ACKNOWLEDGEMENTS. The author acknowledges Universidad de Las Americas (UDLA) for funding research on orchids in Ecuador. We also thank Susann Ziegler Annen and Max Annen-Ziegler, of Switzerland, for being vital supporters and donors who helped make possible the Dracula Reserve managed by Ecominga Foundation. The Ministerio del Ambiente de Ecuador is acknowledged for issuing the Environmental Research Permit No. 008-2016-IC-FLO-DNB/MA. Also Ecominga Foundation for working in conservation of orchids in situ by preserving forests before being cut down.

\section{LiterATURE CiTED}

Chase, M. W., Cameron, K. M., Freudenstein J. V., Pridgeon, A. M., Salazar, G., van den Berg, C. \& Schuiteman, A. (2015). An updated classification of Orchidaceae. Botanical Journal of the Linnean Society, 177, 151-174.

Endara, L., Williams, N. \& Whitten, M. (2011). Filogenia Molecular Preliminar de Scaphosepalum (Orchidaceae: Pleurothallidinae). Lankesteriana, 11(3), 245-252.

Karremans, A. P. (2016). Genera Pleurothallidinarum: an updated phylogenetic overview of Pleurothallidinae. Lankesteriana, 16, 219-241.

Karremans, A. P., Albertazzi, F. J., Bogarin, D., Eurlings, M. C. M., Pridgeon, A., Pupulin, F., \& Gravendeel, B. (2016). Phylogenetic reassessment of Specklinia and its allied genera in the Pleurothallidinae (Orchidaceae). Phytotaxa, 272, 001-036.

Luer, C. A. (1988). Icones Pleurothallidinarum V: Systematics of Dresslerella and Scaphosepalum. Addenda to Porroglossum. Monographs in Systematic Botany from the Missouri Botanical Garden, 26, 21106.

Luer, C. A. (1991). Icones Pleurothallidinarum VIII: Systematics of Lepanthopsis, Octomeria Subgenus Pleurothallopsis, Restrepiella, Restrepiopsis, Salpistele and Teagueia. Addenda to Platystele, Porroglossum and Scaphosepalum. Monographs in Systematic Botany from the Missouri Botanical Garden, 39, 158, 161.

Luer, C. A. (1992). Icones Pleurothallidinarum IX: Systematics of Myoxanthus. Addenda to Platystele, Pleurothallis, subgenus Scopula and Scaphosepalum. Monographs in the Systematic Botany from the Missouri Botanical Garden, 44, 126-127.

Luer, C. A. (1998). Icones Pleurothallidinarum XVI: Pleurothallis Subgenera Crocodeilanthe, Rhynchopera, Talpinaria. Addenda to Dracula, Lepanthes of Ecuador, Masdevallia, Platystele, Pleurothallis, Restrepia and Scaphosepalum. Monographs in Systematic Botany from the Missouri Botanical Garden, 65, 119, 121-122. Luer, C. A. (1998). Icones Pleurothallidinarum XVII: Pleurothallis Subgenus Pleurothallis Sections 
Abortivae, Truncatae, Pleurothallis Subsection Restrepiopsis, Scaphosepalum and Teagueia. Acroniae, Pleurothallis Subgenera Dracontia Monographs in Systematic Botany from the Missouri and Unciferia. Addenda to Dracula, Lepanthes, Masdevallia, Porroglossum and Scaphosepalum. Monographs in Systematic Botany from the Missouri Botanical Garden, 72, 115-117, 120.

Luer, C. A. (2000). Icones Pleurothallidinarum XX: Jostia, Andinia, Barbosella, Barbrodria and Pleurothallis subgenera Antilla, Effusia and Restrepioidia. Addenda to Lepanthes, Masdevallia, Platystele, Pleurothallis, Botanical Garden, 79, 131, 139.

Luer, C. A. (2009). Miscellaneous New Species in the Pleurothallidinae (Orchidaceae). Selbyana, 30, 19-20, 60-61.

Valenzuela Gamarra, L. (2015). A new species of Scaphosepalum Pfitzer (Pleurothallidinae: Orchidaceae), on the humid montane forest from Perú. Arnaldoa, 22, 339-346. 